\title{
SiM
}

\section{Update of the 2014 Drought on California Rangelands}

\author{
By Royce E. Larsen, Marc R. Horney, and Daniel Macon
}

\section{On the Ground}

- Droughts are common on California rangelands.

- The current drought in California is listed as severe or exceptional for most of the state.

- The drought has affected rangeland, and the livestock industry, more than other commodities.

- The actual costs associated with this drought are just beginning to be realized.

Keywords: drought, California, rangelands.

Rangelands 36(5):52-58

doi: 10.2111/Rangelands-D-14-00032.1

(C) 2014 The Society for Range Management

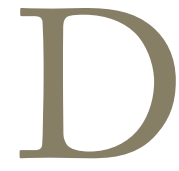

rought is a recurring phenomenon characteristic of arid and semiarid landscapes that challenges efforts to make reliable uses of them. The United States has experienced mounting costs from droughts over the last 30 years. The costs of the 2012 drought alone surpassed $\$ 50$ billion. ${ }^{1}$ In California, as in other western states, costs of the 2014 drought are already significant and growing rapidly. By late spring 2014, preliminary estimates of agricultural economic losses exceeded $\$ 2.2$ billion, and more than 17,000 jobs had been lost. ${ }^{2}$ Though drought impacts many agricultural segments, our main interest here is how it has impacted rangelands in California, particularly rangelands in the Central Coast region.

\section{California Climate and Common Rangeland Types}

Much of California enjoys a Mediterranean climate that is largely unique in North America. It is characterized by cool wet winters and hot dry summers. While occasional weather systems may bring some monsoonal moisture in the summertime, those events are presently rare and short-lived. California's large geographic extent and considerable topographic variation have yielded a great many ecological sites and associated plant communities. One broad division is between the annual grassland type, which commonly exists below 1,200 feet in elevation ${ }^{3}$ and is made up of naturalized species, many introduced from the Mediterranean region of southern Europe, and the perennial-grass-dominated Great Basin sagebrush-steppe type, which is common on the east slope of the Sierra Nevada and Cascade mountains and the Modoc plateau in the NE portion of the state. The annual grasslands of the Central Valley and Central Coast regions are often codominant with oak woodlands or savannas, which in many areas are vestiges of their former extent. ${ }^{4}$ Weather and growing conditions for California rangelands are driven by complex interactions among coastal influences, elevation and other orographic effects, and distribution of summertime heat from the central valleys and southern deserts. Precipitation amounts and patterns can vary substantially over relatively short distances in response to these interactions.

\section{History of Droughts in California}

According to tree ring records there have been several multidecadal dry periods in the past 500 years in California. These records reveal a major dry period from 1760 to $1820^{5}$ and another drought from 1860 to 1885 . Severe droughts in 18501851 and 1862-1864, together with other factors, including grazing practices, have been implicated in the conversion of the former native perennial grassland to a vegetation type that is dominated by annual grasses and forbs. ${ }^{6}$ The severe drought from 1862 to 1864 was also implicated in a major shift from livestock to cropland production in California. ${ }^{7}$

There have been at least eight multiyear periods of low precipitation in California since 1900. Droughts that exceed three years are uncommon, though occurrences in the past century include 1929-1934, 1947-1950, and 1987-1992. One remarkable example of drought in California was the two-year dry period in 1976 and 1977. Precipitation during each of these calendar years ranked among five lowest amounts ever recorded in California. ${ }^{4}$

In some years low precipitation results in forage production that is well below average. Because the amount and dependability of precipitation increases from south to north, and with elevation, the frequency of years with forage production significantly below average varies greatly across the 
Lessons From the Dust Bowl Drought and Rangeland Conversion

By Dan Macon, Flying Mule Farm: A Producer's Viewpoint

In late January 2014, I attended the 9th annual California Rangeland Conservation Coalition summit in Oakdale, California. While past summits have focused on the threats posed by real estate development, this year's event focused on a different and, for me, unexpected threat-the conversion of our rangelands to orchards and vineyards. After returning home from this year's summit, I happened to start watching Ken Burns' latest PBS documentary, The Dust Bowl. As I watched, I was struck by the similarity between the attitudes and actions of farmers in the Southern Plains in the years leading up to the Dust Bowl and our own efforts to convert "unproductive" grasslands into intensively farmed orchards. At the risk of being melodramatic, I think we should consider the lessons of the Dust Bowl and the parallels with today's rangeland conversion in California.

My own "sheepherder" definition of rangeland is any land that is too steep, too dry, too wet, too "something" for cultivated agriculture. Prehistorically, our rangelands were grazed by wild ungulates. Today, California's rangelands are the foundation of our livestock industry: cattle and sheep have grazed on rangelands in California for more than two and a half centuries. Rangelands continue to provide habitat for an incredible array of wildlife and native plants-everything from raptors to reptiles and the majestic oak to the smallest wildflower. Scientists are increasingly convinced that well-managed livestock grazing is crucial to the health of the native flora and fauna on our rangelands. And ranching, as an economic endeavor, is crucial to keeping these rangelands intact: it seems that ranching and wildlife both require large, contiguous tracts of open land.

The wheat boom of the 1920 s resulted in the plowing of native prairie and planting of wheat on millions of acres in the Southern Plains. The price of wheat, driven up by World War I, seemed to be on an endless upward path. Even though the Plains were prone to periodic drought, historian Donald Worster says, "Promoters promised that the very act of farming would increase the precipitation-the rain follows the plow." Wayne Lewis, who grew up on a farm in the Oklahoma panhandle, adds, "In the late 20 s, the crops were good, the prices were good and so everybody ... the thing to do was to break out everything and get it in wheat." ${ }^{18}$

Not everyone was convinced that the wheat boom was beneficial or sustainable. According to Duncan, ${ }^{18}$ "A handful of old timers, especially the cattlemen who had been there through those droughts, weren't so sure [about sod-busting the Plains]. To them, the Southern Plains were a grassland and the sod should never be turned." Following the stock market crash in 1929 and several years of record wheat crops, the price of wheat crashed. As prices fell, the federal government encouraged farmers to plant state's annual-type rangelands. Analysis of annual forage production data from 26 locations in California's annual rangelands reveal that a $50 \%$ reduction in range forage production rarely occurs north of Sacramento. ${ }^{8}$ The $50 \%$ reduction value is important because that is the value used by the USDA Farm Service Agency to begin offering assistance programs like the Noninsured Crop Disaster Assistance Program. Forage losses greater than $50 \%$ are more common in the rain shadow of the Coast Range adjacent to the west edge of the San Joaquin Valley. ${ }^{8}$

California's annual rangeland forage production also varies greatly over short distances due to variations in precipitation, soil characteristics, and topography. For example, data from San Luis Obispo County reveal that forage reductions are less frequent at coastal sites than inland sites. ${ }^{9}$ This high variability from year to year and from site to site makes it difficult for producers to manage livestock enterprises.

\section{Current Drought in California}

\section{State of the Drought}

The current drought in California has placed the majority of the state in the severe or exceptional drought category according to the US Drought Monitor. ${ }^{10}$ Even though this year has received much attention from the media, California has actually been experiencing drought conditions for at least six out of the last eight years (Fig. 1). The 2013-2014 water year was exceptionally low in rainfall and snowpack, and most reservoirs did not fill to capacity, many communities are demanding water cuts, crops are not being watered, and forage production for livestock was significantly below average this year. A recent report shows that the 2014 drought is responsible for the greatest reduction in surface water availability ever measured. ${ }^{2}$ Groundwater is expected to make up 75\% (5 million acre-feet) of the water shortage ( 6.5 million acre-feet) for agriculture during 2014. In addition to higher pumping costs, this could lead to depletion of groundwater sources, wells may dry up, and land may subside. The net water shortage will affect the Tulare Basin, in the southern Central Valley the most, ${ }^{2}$ which is in the "exceptional drought" zone. Although most crops may be irrigated by pumping groundwater, where available, rangeland productivity depends on rainfall. Rangeland use is not only dependent on forage availability but water availability as well. It has not been uncommon for pastures to be left with forage still available simply because drinking water sources for livestock, whether stockwater ponds, streams, springs, or wells, have run dry.

It is common that droughts affect the areas south of Sacramento more often than those north of Sacramento. ${ }^{8}$ The Central Coast of California, which is more than 200 miles south of Sacramento, is in the heart of the D4 (Exceptional) drought rating area of the state (Fig. 1). Within this area, the city of Paso Robles, California, has kept rainfall records since 1887 (Fig. 2). The water years 2006-2007, 2008-2009, 20112012, 2012-2013, and 2013-2014 were all well below average. Annual forage production has been monitored in San Luis 

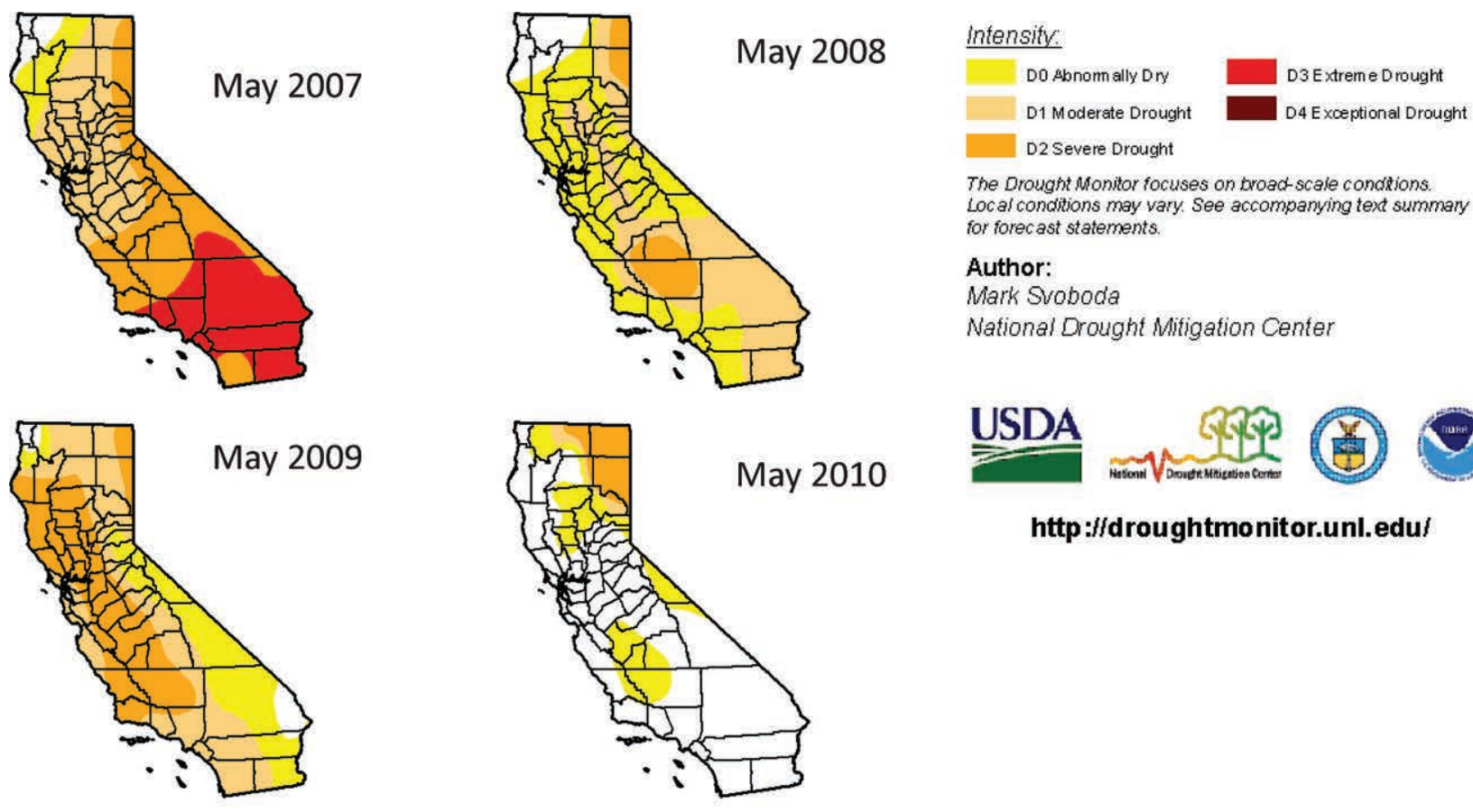

The Drought Monitor focuses on broad-scale condtions Local conditions may vary. See accompanying text summary for forecast statements.

\section{Author:}

Mark Svoboda

National Drought Mitigation Center

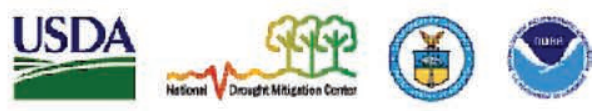

http ://droughtmonitor.unl.edu/
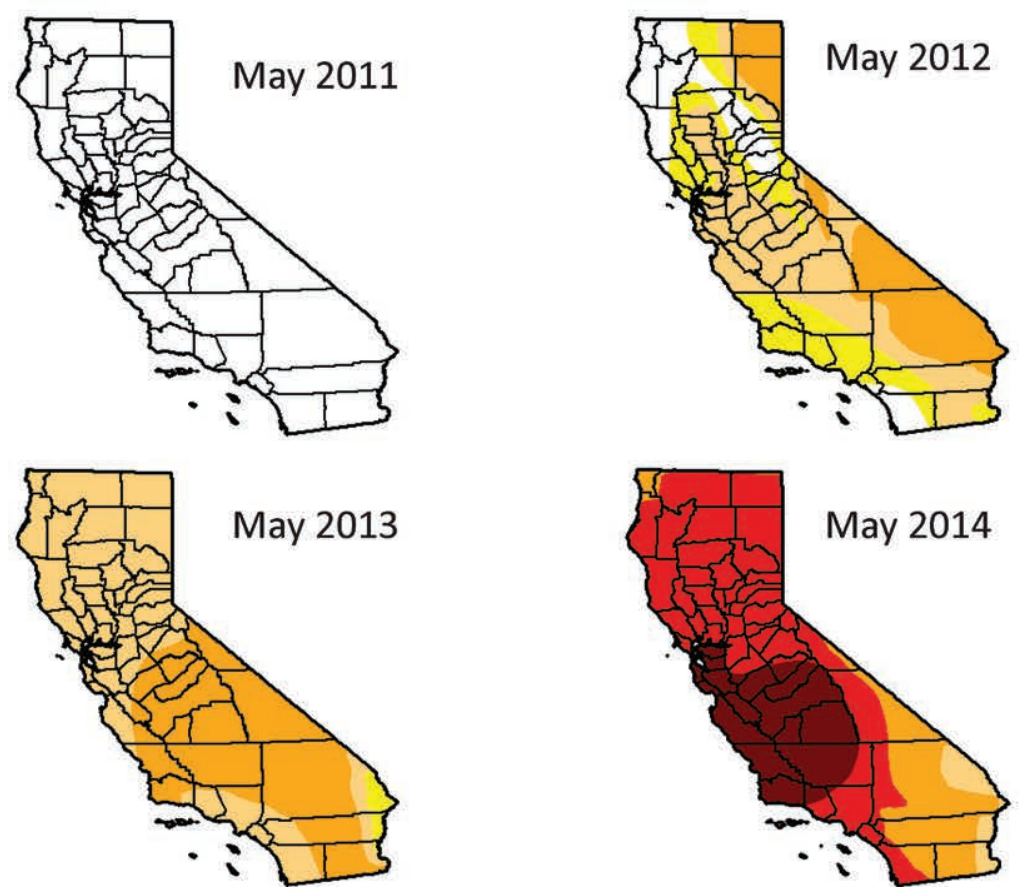

Figure 1. A graphical representation of the drought progression in California from 2007 through 2014. Shown at the time of peak forage production, during the first week of May each year. ${ }^{10}$

Obispo County since 2001. ${ }^{9}$ Forage production losses were well below average during those same years (Fig. 3).

In San Luis Obispo County, forage production losses exceeded 83\% for the 2013-2014 growing season (Fig. 3). Western Madera and Fresno Counties, also in the D4 rated area, had forage production losses of greater than $85 \%$. But the eastern portions of Madera and Fresno Counties, which are in the western foothills of the Sierra Nevada mountain range, were only $40 \%$ below average. ${ }^{11}$ North of Sacramento, the forage production at the Sierra Foothill Research and Extension Center and the Hopland Research and Extension Center was only 15\% below average (J. Harper, personal communication, 2014).$^{12}$ It appears that the extreme forage production losses follow closely with the drought monitor rating for the state (Fig. 1). 


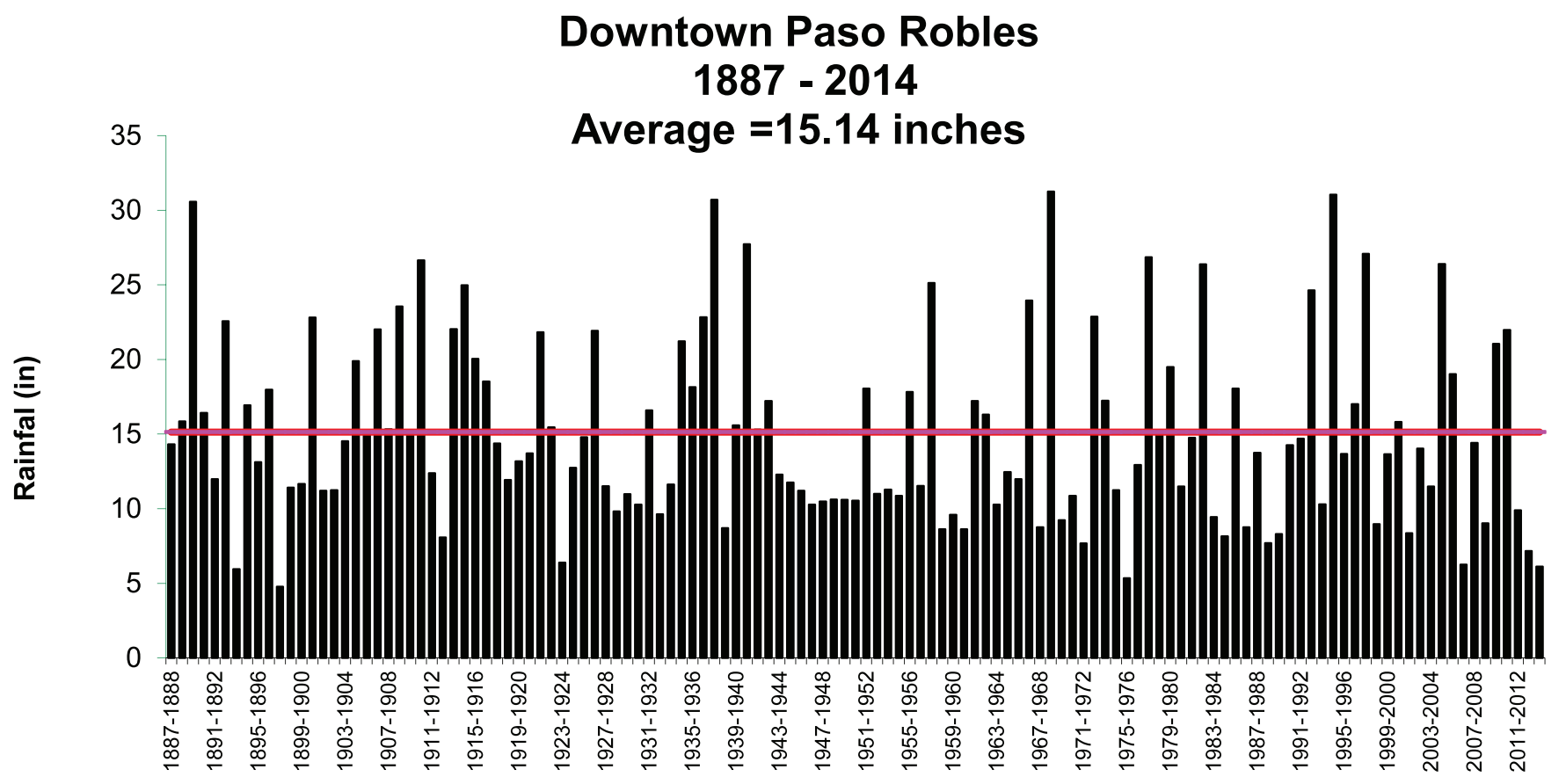

Figure 2. Rainfall records from 1887 to 2014 water year showing high yearly variations.

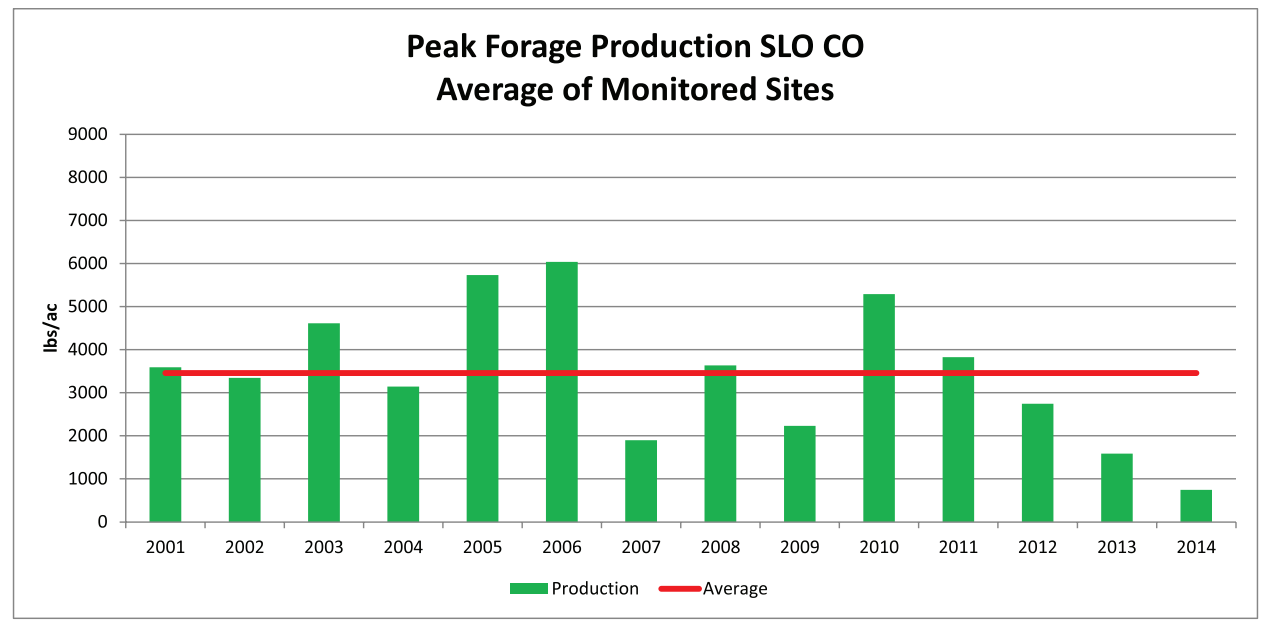

Figure 3. Forage production for monitored sites spread across San Luis Obispo County, California, since 2001. Values represent peak production during late April or early May.

Even though the southern portion of the state experienced greater forage production losses than the north, the growing season for the entire state was changed dramatically. There was not enough rainfall for germination until end of February 2014. Germination usually occurs by October or November, with a slow growing period through the cool winter $\left(50-65^{\circ} \mathrm{F}\right)$ and accelerating growth as temperatures warm in early spring while water remains available. ${ }^{13}$ During the 2013-2014 growing season, there was no green feed for livestock until March 2014, five months later than normal.

This "late green feed period of 2014" was further amplified south of Sacramento within the exceptional droughtrated area. For example, in San Luis Obispo County, 21 dif- ferent sites were monitored for forage production in 2014. There were some locations with very limited rainfall and forage production was so low it did not even meet the recommended residual dry matter standards. ${ }^{14}$ This means there was no herbaceous feed available for livestock in many parts of the county (Fig. 4). Figure 5 shows the approximate location and rainfall zone of each site sampled within San Luis Obispo County, California.

\section{Implications of Drought}

In a survey of 507 California ranchers, more than $75 \%$ indicated that a drought that was either "as severe as" or "worse than" droughts prior to 2011 would severely impact the eco- 


\section{Available Forage, San Luis Obispo County, California}

2014

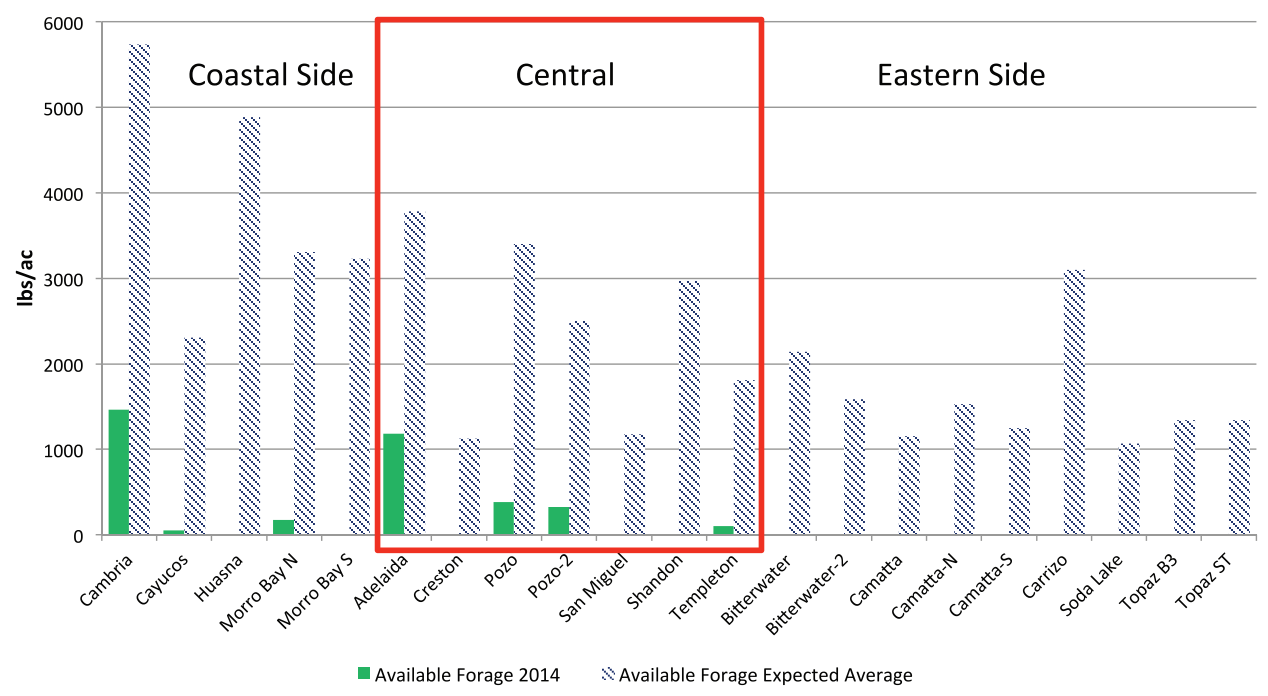

Figure 4. Available forage (herbaceous feed) thoughout San Luis Obispo County, 2014. Available forage (herbaceous feed) is the annual production minus the recommended residual dry matter amount. Many sites had no available forage (100\% loss); overall losses were approximately $95 \%$ across all sites.

\section{Lessons continued}

less. On the contrary, everyone planted more-to make up for lower prices with higher volume. And then it stopped raining. America's greatest economic disaster became its greatest ecological disaster-due, at least in part, to the conversion of rangeland to cropland.

So how does the wheat boom of the 1920s and the Dust Bowl of the 1930s in the Great Plains relate to rangeland conversion and orchard development in 21 st-century California? To me, there seem to be a number of similarities. Roger Duncan, the UC Cooperative Extension Horticulture and Pomology Advisor for Stanislaus County, says that between 1992 and 2012, almond acreage in California increased by 74 percent. Pistachio acreage was up by $108 \%$, and vineyard acreage increased by $66 \%$. While some of these plantings occurred on vegetable and field crop land, the greatest impact has been to rangeland. ${ }^{19}$

New technology is making orchard development on formerly unirrigated rangelands possible. This conversion is being driven by economic factors. In general, a rancher needs approximately 12 acres of unirrigated rangeland to support one cow and her calf for a year. For a 300 cow operation, the annual net return per acre is $\$ 1.02 .^{20}$ Planted to almonds, this acre of land would produce an annual net return of $\$ 195$ per acre, ${ }^{21}$ and walnuts would generate annual net returns of $\$ 1,442$ per acre. ${ }^{22}$ According to Duncan, $82 \%$ of the world's almonds are grown in California. In 2013, Blue Diamond Almond reported that "demand will continue to outstrip supply." Duncan believes that conversion will stop only when California runs out of land and water. At least to me, the situation on California's rangelands seems eerily reminiscent of the situation on the Great Plains in the late 1920s. And now it's stopped raining.

In some respects, this conversion is too recent to fully understand the ecological and community implications. Anecdotally, however, some impacts are already being felt. Lower groundwater tables have created conflicts among landowners in Stanislaus County. In Merced County, land subsidence is apparently linked to groundwater overdraft from deep wells in orchards. Other impacts, like those to rangeland vegetation and wildlife, have not been studied yet.

Fortunately, many of the academics, ranchers, and environmentalists who are part of the California Rangeland Conservation Coalition are starting to search for answers. Sheila Barry, a livestock and natural resources advisor with UC Cooperative Extension in the Bay Area, focuses on the economics. "The disparity is so great [between rangeland livestock production and orchard production]," she says, "that progress towards a level playing field will only come from finding ways to pay for non-production values [like wildlife habitat] produced by ranchers and ranches." She adds, "We have to find ways to reduce the cost of doing business, e.g. estate tax policy shouldn't be pushing people to convert the ranches" (S. Barry, personal communication, 2014).

I'll admit to mixed feelings about this trend. I've always viewed residential development as the greatest threat to our rangeland agriculture. At least an orchard keeps land in agriculture. I've started to realize, however, that our society is wonderfully adept at figuring out how to do things-we've figured out how to grow orchards on lands that we once thought were unsuitable to orchard production. We are less adept at asking ourselves, "Should we do this?" 


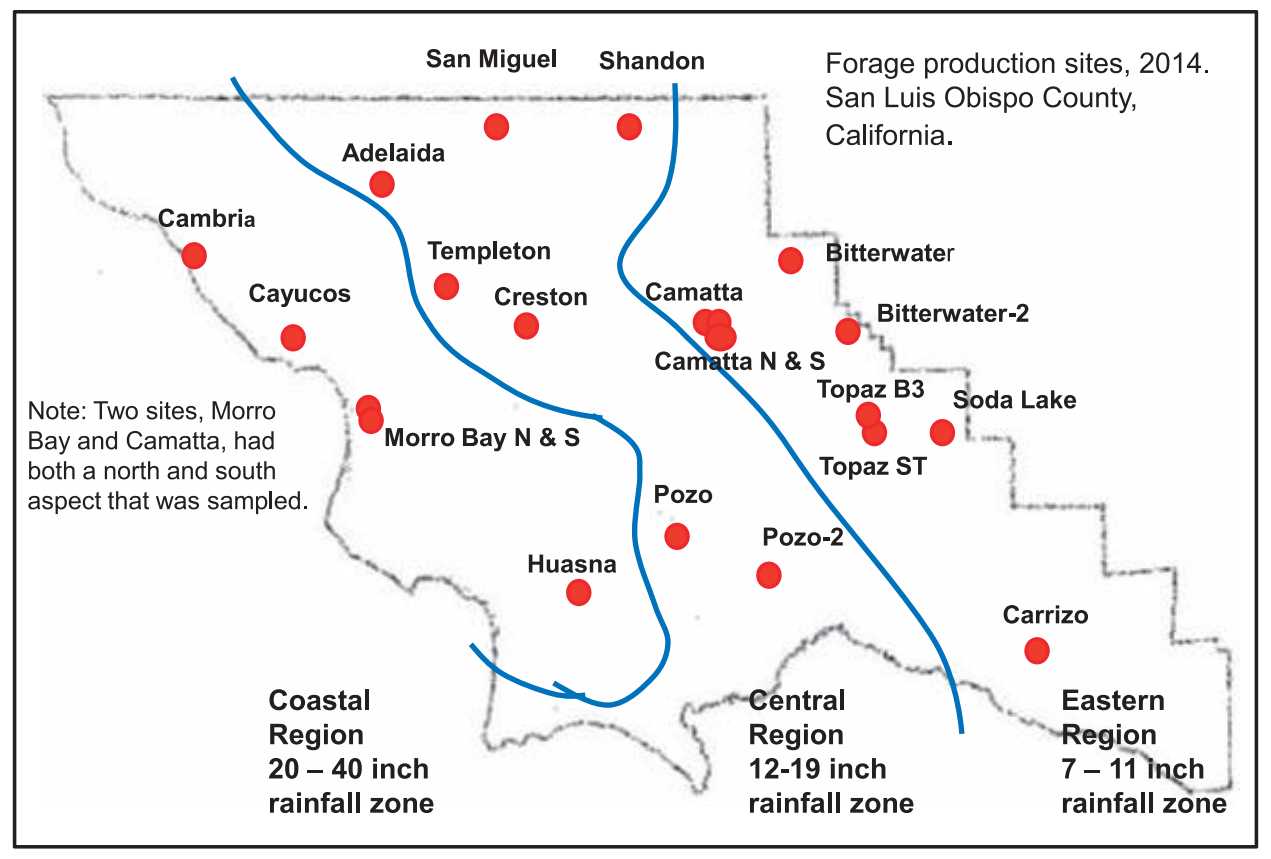

Figure 5. Approximate location of the forage production sites. The coastal region has the highest average annual rainfall, while the eastern side of the county has the least rainfall.

nomic viability of their operation. ${ }^{15}$ Rancher experience and knowledge were two of the most important tools a rancher could have to help with drought management strategies. ${ }^{15}$ Ranchers that were interviewed by media during this drought anticipated that it may take four to five years to rebuild their herds after the rains begin again. ${ }^{16}$ Many livestock producers have sold most of their herd, or at least significantly reduced their numbers, especially in areas south of Sacramento. The San Luis Obispo County Cattlemen's Association reported that more than 10,000 head of butcher cows went through the primary local auction yard from October 2013 to March 2014. The normal number would be 1,400 head (D. Dock, personal communication, 2014). Many producers have reported that they are selling calves smaller and younger, selling pairs, culling more than normal-anything they can do to survive the drought, ${ }^{16,17}$ and severe impacts are expected from this drought. ${ }^{18}$

Some producers have stated that the drought today could change the future of agriculture. ${ }^{16}$ There is currently a move to take rangeland out of production by adding vineyards and orchards, and at least some producers are just selling their ranch (Fig. 6). Many acres of rangeland on the Central Coast are being converted to vineyards, while many acres in the Central Valley are being converted to almond orchards. With the current economic markets, it makes sense to convert rangelands to other crops. But these other crops require irrigation, which could be severely curtailed if this drought continues. With late rains of 2013-2014, which caused the limited feed for livestock, some producers felt like they were back in the Dust Bowl days of the 1930s.

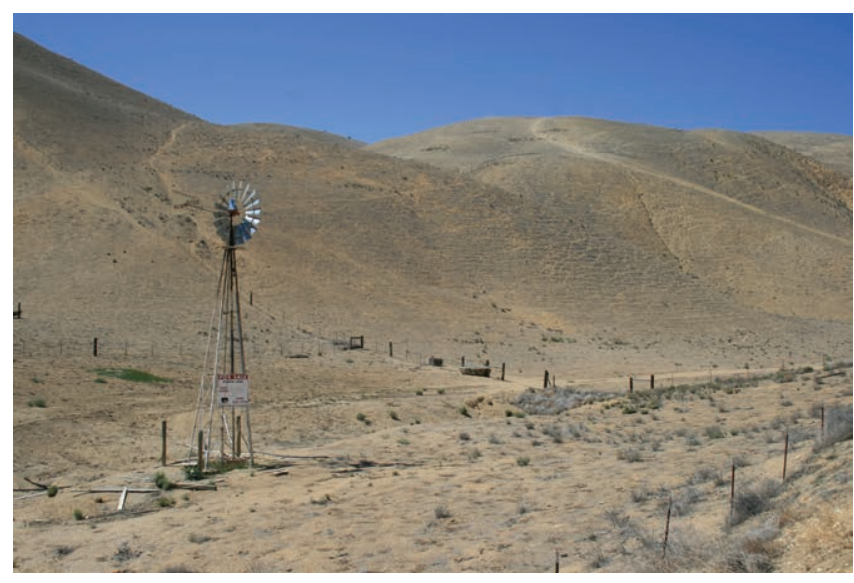

Figure 6. Peak production on California's annual rangelands, eastern side of San Luis Obispo County. Photo taken on 28 April 2014. This photo shows how serious the drought in this area is, which had less than 2 inches of rainfall, and there was no forage available for livestock.

\section{Conclusions}

Though droughts are common in California, this is the worst drought the state has seen in a long time. The extreme reduction in forage availability for such an extended period has led many livestock producers to substantially reduce or eliminate their herds. With this current drought, and other economic drivers, many acres of rangeland are now being converted to vineyards and tree crops such as almonds and walnuts. It will take several years for producers to rebuild their herds to full capacity after the weather returns to normal. This paper reports only some preliminary effects of the current drought. 
The full effects on, for example, the livestock industry, ecosystem health (both flora and fauna), snow pack, and irrigation are yet to be determined.

\section{References}

1. National Drought Forum. 2012. Drought and U.S. preparedness in 2013 and beyond. Summary report and priority actions. Prepared by the National Integrated Drought System. Available at: www.drought.gov. Accessed 6 June 2014.

2. Howitt, R. E., J. Medellin-Azuara, D. MacEwan, J. R. Lund, And D. A. Sumner. 2014. Economic analysis of the 2014 drought for California agriculture. Davis, CA, USA: Center for Watershed Sciences, University of California, Davis. 20 p. Available at: https://watershed.ucdavis.edu. Accessed 20 July 2014.

3. California Native Plant Society. 2000. A manual of California vegetation. Available at: http://davisherb.ucdavis.edu/ CNPSActiveServer/SeriesDetail.aspx? seriesname $=$ California + annual+grassland+series. Accessed 27 July 2014.

4. George, M. R. 2014. Annual rangeland handbook, chapter 1: Mediterranean climate. Available at: http://californiarangeland. ucdavis.edu/Mediterranean_Climate/. Accessed 20 July 2014.

5. Fritts, H. C., And G. A. Gordon. 1980. Annual precipitation for California since 1600 reconstructed from western North American tree rings. Sacramento, CA, USA: California Department of Water Resources. 45 pp.

6. D’Antonio, C. M., S. J. Bainbridge, C. Kennedy, J. W. Bartolome, and S. Reynolds. 2007. Ecology and restoration of California grasslands with special emphasis on the influence of fire and grazing on native grassland species. Berkeley, CA, USA: University of California, Berkeley. 99 p. Available at: http:// globalrestorationnetwork.org/uploads/files/LiteratureAttachments/ 120_ecology-and-restoration-of-california-grasslands-withspecial-emphasis-on-the-influence-of-fire-and-grazing-onnative-grassland-species.pdf. Accessed 8 September 2014.

7. Crawford. 1991. The Great Drought: fickle weather in 1860s led to breakdown of cattle industry. Available at: http://articles. latimes.com/1991-06-13/news/nc-780_1_cattle-industry. Accessed 21 July 2014.

8. George, M. R., R. E. Larsen, N. M. McDougald, C. E. Vaughn, D. K. Flavell, D. M. Dudley, W. E. Frost, K. D. Striby, and L. C. Forero. 2010. Determining drought on California's Mediterranean-type rangelands: the noninsured crop disaster assistance program. Rangelands 32(3):16-20.

9. Larsen, R. E., And M. Horney. 2014. Forage production report 2014 San Luis Obispo County. Available at: http:// cesanluisobispo.ucanr.edu/Custom_Program355/Forage_ Production_Report. Accessed 15 July 2014.

10. US Drought Monitor. Available at: http://droughtmonitor. unl.edu. Accessed 6 June 2014.

11. Dudley, D., And N. McDougald. 2014. NRCS Report. Forage production in Madera and Eastern Fresno Counties. Report to the USDA Farm Service Agency. Madera, CA, USA: Natural Resource Conservation Services. 3 p.

12. Sierra Foothill Research and Extension Center. 2014. Range forage production monitoring. Available at: http://sfrec. ucanr.edu/files/192498.pdf. Accessed 25 July 2014.

13. George, M., and K. Rice. 2014. Annual rangeland handbook, chapter 5: range plant growth and development. Available at: http://californiarangeland.ucdavis.edu/Range_Plant_Growth_ and_Development/. Accessed 25 July 2014.

14. Bartolome, J. W., W. E. Frost, N. K. McDougald, and M. Connor. 2006. California guidelines for residual dry matter (RDM) management on coastal and foothill annual rangelands. Oakland, CA, USA: Division of Agriculture and Natural Resources, University of California, Publication 8092.8 p.

15. Roche, L., And K. Tate. 2014. Drought: ranchers' perspective and management strategies. Policy brief, May. Available at: http://policyinstitute.ucdavis.edu/files/Roche-2014.pdf. Accessed 6 July 2014.

16. SNEed, D., ANd J. LAvelle. 2014. Drought forcing local ranchers to sell off cattle. Available at: http://www.sanluisobispo. com/2014/01/30/2901541/ranchers-selling-cattle-drought. html. Accessed 6 June 2014.

17. Huffstutter, P.J., And T. Polansek. 2014. Drought sends California cattle packing. Available at: http:/www.reuters.com/article/ 2014/04/28/us-usa-drought-cattle-idUSBREA3R0O320140428. Accessed 6 June 2014.

18. Burns, K. 2012. The Dust Bowl. PBS (DVD).

19. Duncan, R. 2014. Where and why will trees replace rangelands. California Rangeland Conservation Coalition Summit, 21 January 2014; Oakdale Community Center, Oakdale, CA, USA.

20. Forero, L., G. Nader, K. Klonsky, and R. De Moura. 2008. Sample costs for beef cattle cow-calf production. Available at: http://ceshasta.ucanr.edu/files/115418.pdf. Accessed 28 July 2014.

21. Duncan, R., P. Verdegaal, B. Holtz, D. Doll, K. Klonsky, and R. De Moura. 2011. Sample costs to establish an orchard and produce almonds. Cost studies from UC Davis. Available at: http://coststudies.ucdavis.edu/current.php. Accessed 27 July 2014.

22. Grant, J., J. Caprile, D. Doll, K. Anderson, K. Klonsky, and R. De Moura. 2013. Sample costs to establish a walnut orchard and produce walnuts. Cost studies from UC Davis. Available at: http://coststudies.ucdavis.edu/current.php. Accessed 27 July 2014.

Authors are Area Natural Resource Watershed Advisor, University of California, Division of Agriculture and Natural Resources, Templeton, CA 93465, USA, relarsen@ucanr.edu (Larsen); Assistant Professor, California Polytechnic University, Rangeland Resources Program, San Luis Obispo, CA 93441, USA (Horney); and Owner, Flying Mule Farm, Auburn, CA 95602, USA (Macon). 